\title{
Site C0018
}

M. Strasser, B. Dugan, K. Kanagawa, G.F. Moore, S. Toczko, L. Maeda, Y. Kido, K.T. Moe, Y. Sanada, L. Esteban, O. Fabbri, J. Geersen, S. Hammerschmidt, H. Hayashi, K. Heirman, A. Hüpers, M.J. Jurado Rodriguez, K. Kameo, T. Kanamatsu, H. Kitajima, H. Masuda, K. Milliken, R. Mishra, I. Motoyama, K. Olcott, K. Oohashi, K.T. Pickering, S.G. Ramirez, H. Rashid, D. Sawyer, A. Schleicher, Y. Shan, R. Skarbek, I. Song, T. Takeshita, T. Toki, J. Tudge, S. Webb, D.J. Wilson, H.-Y. Wu, and A. Yamaguchi²

\section{Chapter contents}

Background and objectives........... 1

Operations......................

Logging while drilling.............

Core-log-seismic integration. .........

References.................... 7

Figures.................. 9

Table ..................... 21

${ }^{1}$ Strasser, M., Dugan, B., Kanagawa, K., Moore, G.F., Toczko, S., Maeda, L., Kido, Y., Moe, K.T., Sanada, Y., Esteban, L., Fabbri, O., Geersen, J., Hammerschmidt, S., Hayashi, H., Heirman, K., Hüpers, A., Jurado Rodriguez, M.J., Kameo, K., Kanamatsu, T., Kitajima, H., Masuda, H., Milliken, K., Mishra, R., Motoyama, I., Olcott, K., Oohashi, K., Pickering, K.T., Ramirez, S.G., Rashid, H., Sawyer, D., Schleicher, A., Shan, Y., Skarbek, R., Song, I., Takeshita, T., Toki, T., Tudge, J., Webb, S. Wilson, D.J., Wu, H.-Y., and Yamaguchi, A., 2014. Site C0018. In Strasser, M., Dugan, B., Kanagawa, K., Moore, G.F., Toczko, S., Maeda, L., and the Expedition 338 Scientists, Proc. IODP, 338: Yokohama (Integrated Ocean Drilling Program). doi:10.2204/iodp.proc.338.105.2014

'Expedition 338 Scientists' addresses.

\section{Background and objectives}

During Integrated Ocean Drilling Program (IODP) Expedition 338, a slope basin seaward of the megasplay fault was logged with logging while drilling (LWD)/measurement while drilling (MWD) at Site C0018. The slope basin, characterized in 3-D seismic data by stacked mass transport deposits (MTDs) (Strasser et al., 2011) was drilled and sampled during IODP Expedition 333 in Hole C0018A (Fig. F1) (Expedition 333 Scientists, 2012a). The primary goals of operations at Site C0018 were to establish the stratigraphy of Quaternary mass-movement events and to sample the distal part of an exceptionally thick MTD for analyzing its rheological behavior to constrain sliding dynamics and tsunamigenic potential.

Site C0018 (proposed Site NTS-1A; water depth $=3084.35 \mathrm{~m}$ ) is located $\sim 5 \mathrm{~km}$ southwest of IODP Sites C0004 and C0008, which were drilled and cored during IODP Expedition 316 (Screaton et al., 2009) (Figs. F1, F2). Site C0018 is located within a lower slope basin that (1) represents the depocenter for downslope mass transport, (2) is characterized by stacked MTDs that were seismically identified as acoustically transparent to chaotic bodies with ponded geometries (Fig. F2), and (3) includes a large (as thick as $182 \mathrm{~m}$ ) MTD (Strasser et al., 2011). Hole C0018A was drilled at a location where the MTD bodies wedge out and basal erosion is thought to be minimal. Coring to $\sim 314.15$ meters below seafloor (mbsf) allowed sampling of the MTDs across this stratigraphic succession.

Sediment cored in Hole C0018A are divided into two lithologic subunits. Lithologic Subunit IA (0-190.65 mbsf) is primarily composed of hemipelagic mud (i.e., silty clay) with interbedded volcanic ash layers and is affected by MTDs, whereas lithologic Subunit IB (190.65-313.65 mbsf) is a sandy turbidite sequence (Expedition 333 Scientists, 2012a; Strasser et al., 2012). Six MTDs (numbered 1-6 from top to bottom) ranging in thickness from 50 $\mathrm{cm}$ to $61 \mathrm{~m}$ are identified within Subunit IA (Expedition 333 Scientists, 2012a; Strasser et al., 2012) (Fig. F3). These MTDs are composed of chaotic and convolute bedding with intervals of coherent bedding and commonly have bases defined by shear zones. A mass-movement event related to deposition of the lowermost and most prominent MTD 6 is younger than $1.05 \mathrm{Ma}$ (because an ash layer immediately below the thick MTD 6 is identified as the one dated on land as $1.05 \mathrm{Ma}$ ) but older than $0.85 \mathrm{Ma}$, as constrained 
by another marker ash layer overlying MTD 6 (Expedition 333 Scientists, 2012a; Strasser et al., 2012). Another mass-movement event related to the uppermost MTD 1 occurred later than $0.291 \mathrm{Ma}$, which is the age indicated by nannofossils $\sim 10 \mathrm{~m}$ below this MTD (Expedition 333 Scientists, 2012a; Strasser et al., 2012). The ages of other MTDs are not well constrained.

During Expedition 338, LWD in Hole C0018B was conducted as a contingency operation. It provided a high-resolution data set of natural gamma radiation (NGR) and resistivity as well as resistivity images to $350 \mathrm{mbsf}$, enabled us to correlate and integrate these data with core and seismic data of the MTDs, and hence enabled us to understand the comprehensive nature of MTDs and their bearing on sliding dynamics and tsunamigenic potential.

\section{Operations}

\section{Hole C0018B}

The D/V Chikyu moved to Site C0018 (water depth = $3084.5 \mathrm{~m}$ ) after completing all operations at Site C0002. Making up and running the LWD bottomhole assembly (BHA) started at $1400 \mathrm{~h}$ on 25 December 2012. The 121/4 inch LWD BHA components were similar to Hole $\mathrm{C} 0012 \mathrm{H}$ operations with the exception of the sonicVISON tool, which was not used in Hole C0018B. Function tests on the LWD were conducted at 76, 1060, 2006, and $3100 \mathrm{~m}$ drilling depth below rig floor (DRF), respectively, while lowering the LWD BHA. Spud-in of Hole C0018B was confirmed by real-time resistivity data at $0430 \mathrm{~h}$ on 26 December. Washing down with a controlled rate of penetration (ROP) at an average of $40 \mathrm{~m} / \mathrm{h}$ (maximum $=50 \mathrm{~m} / \mathrm{h}$ ) changed to drilling ahead from 40 mbsf at $0600 \mathrm{~h}$. Rotation speed was gradually increased step-wise to total depth (350 mbsf): $15 \mathrm{rpm} \times$ $1.8-2.5 \mathrm{kNm}$ (40-45 mbsf), $30 \mathrm{rpm} \times 0-5.0 \mathrm{kNm}(45-$ $50 \mathrm{mbsf}), 45 \mathrm{rpm} \times 0-5.0 \mathrm{kNm}(50-67 \mathrm{mbsf}), 60 \mathrm{rpm}$ $\times 0-5.0 \mathrm{kNm}(67-242 \mathrm{mbsf})$, and $80 \mathrm{rpm} \times 1.6-8.3$ $\mathrm{kNm}$ (242-350 mbsf). The target depth was reached by $1130 \mathrm{~h}$ on 26 December. After spotting kill mud, the LWD BHA was pulled out of the hole to $2813 \mathrm{~m}$ DRF (300 $\mathrm{m}$ above the seafloor) by $2000 \mathrm{~h}$ on $26 \mathrm{De}-$ cember in preparation for operations at Site C0021.

\section{Logging while drilling}

LWD and MWD data were collected in Hole C0018B through slope-basin sediment to a total depth of 350.0 mbsf. Schlumberger's MWD TeleScope tool provided drilling parameters, and the LWD geoVISION tool recorded gamma ray, resistivity, and azimuthal resistivity images (see the "Methods" chap- ter [Strasser et al., 2014a]). Both real-time and memory data were collected. Overall, data quality was found to be good, with the exception of the upper interval ( $0-47 \mathrm{mbsf})$ of the resistivity images, which is missing because of wash down. The gamma ray, resistivity, and resistivity images were interpreted for lithologic and structural features, with two clear subunits identified in the slope sediment and evidence for two MTDs. Porosity and bulk density were calculated from resistivity data, and in situ stress orientations were determined from breakout orientations.

\section{Data processing}

The seafloor was confirmed at $3113.0 \mathrm{~m}$ DRF, based on the NGR and resistivity curves extracted from the memory data.

\section{Data quality}

The overall quality of the processed logging data was found to be good. Because of no rotation during wash down and ROP exceeding $40 \mathrm{~m} / \mathrm{h}$, resistivity images were not produced above $3160 \mathrm{~m}$ DRF (47 mbsf). Sharp horizontal lines, artifacts from ship heave and pipe vibration, were observed throughout the processed resistivity images. Missing data caused by high stick-slip (>300 cycles/min) were also observed. Breakouts were regularly observed at depths corresponding to pipe connections.

\section{Logging units and lithostratigraphy}

Site C0018 is located in a region of large MTDs and was cored during Expedition 333 (Expedition 333 Scientists, 2012b). Data from the downhole tools were assessed in terms of realistic values for the known lithology of the recovered core. Hole C0018B penetrated slope-basin sediment, which was defined as Unit I during previous expeditions. To maintain consistency, only one logging unit is defined encompassing the entire hole (0-350.0 mbsf). The gamma ray log supports this classification, as its character does not change significantly through the entire drilled section; however, two subunits were identified based on changes in the character of the resistivity logs (Fig. F4; Table T1). In Hole C0018A, six MTDs were identified between 0 and 190 mbsf (Expedition 333 Scientists, 2012b); although these MTDs are unidentifiable from the gamma ray and resistivity logs alone, evidence is seen in the resistivity images (see "Resistivity image analysis").

\section{Subunit IA (0-179.8 mbsf)}

The gamma ray log exhibits only minor variations through Subunit IA, fluctuating around a constant 
baseline of $\sim 75$ gAPI, and resistivity also exhibits overall low variability through this subunit (Fig. F5). From 0.0 to $14.8 \mathrm{mbsf}$, gamma ray values gradually increase from 29 to 75 gAPI, and resistivity also exhibits a gradual increase $(0.3-0.9 \Omega \mathrm{m})$. Below 14.8 mbsf, gamma ray values fluctuate between $\sim 45$ and $\sim 105$ gAPI around the baseline of $\sim 75$ gAPI. From 14.8 to $179.8 \mathrm{mbsf}$, the gamma ray log exhibits repeated $10-20 \mathrm{~m}$ scale increasing and decreasing gamma ray cycles interpreted as coarsening- and fining-upward cycles. Between 101.3 and 179.8 mbsf, the interpreted coarsening- and fining-upward cycles are thinner, occurring over a few meters. The resistivity logs exhibit a similar character. From 14.8 to 23.5 mbsf, resistivity is constant at $\sim 0.9 \Omega \mathrm{m}$, with only minor fluctuations; a sharp spike to $0.75 \Omega \mathrm{m}$ at 23.5 mbsf corresponds to low gamma ray values ( $\sim 53$ gAPI). Another spike to low resistivity $(\sim 0.6 \Omega \mathrm{m})$ occurs at $29.1 \mathrm{mbsf}$, but no observed change in gamma ray values was found at this horizon. Between 29.1 and 39.7 mbsf, resistivity is constant at $\sim 1.0 \Omega \mathrm{m}$ with minor fluctuations. From 39.7 to $44.7 \mathrm{mbsf}$, resistivity gradually increases to $\sim 1.2 \Omega \mathrm{m}$ before gradually decreasing back to $1.0 \Omega \mathrm{m}$ at $54.0 \mathrm{mbsf}$. Resistivity remains constant $(\sim 1.0 \Omega \mathrm{m})$ to $90.25 \mathrm{mbsf}$, where it increases to $1.2 \Omega \mathrm{m}$ over a $3 \mathrm{~m}$ interval before returning gradually to $\sim 1.0 \Omega \mathrm{m}$ by $95.4 \mathrm{mbsf}$. From 95.4 mbsf to the base of Subunit IA (179.8 mbsf), resistivity exhibits repeated increasing and decreasing profiles (ranging from 1.20 to $0.92 \Omega \mathrm{m}$ ), reflecting the interpreted coarsening- and fining-upward sequences in the gamma ray log, and an area of highangle and variable dip (Fig. F4). The base of Subunit IA is placed where resistivity sharply drops to 0.2 $\Omega \mathrm{m}$.

\section{Subunit IB (179.8-350.0 mbsf)}

Within Subunit IB, the gamma ray log exhibits similar characteristics to Subunit IA (Fig. F6) but fluctuates around a slightly higher gamma ray baseline of 85 gAPI. Interpreted coarsening- and fining-upward packages on the 5-10 $\mathrm{m}$ scale are observed throughout this subunit. Two prominent gamma ray lows of $\sim 35$ and $~ 55$ gAPI occur at 205.4-206.5 and 208.3$210.0 \mathrm{mbsf}$, respectively. A corresponding low in resistivity $(0.9 \Omega \mathrm{m})$ is observed between 205.4 and 206.5 mbsf, suggesting the presence of a thick, permeable sand horizon.

Through Subunit IB resistivity exhibits a very different character to Subunit IA, with continuous fluctuations between high and low values (between $>3.0$ and $0.8 \Omega \mathrm{m}$ ) over narrow $(<1-2 \mathrm{~m})$ depth intervals, possibly indicative of thin, interbedded sand/ash and muddy sediment. Within Subunit IB, three intervals are identified based on changes in resistivity character (Table T1; Fig. F6). Subunit IBi (179.8$230.9 \mathrm{mbsf}$ ) is directly below the base of Subunit IA. The subunit exhibits three prominent resistivity lows $(\sim 0.3,0.54$, and $0.6 \Omega \mathrm{m}$ at $179.9,181.6$, and 182.8 mbsf, respectively) and then fluctuates at $\sim 1.4 \Omega \mathrm{m}$ $( \pm 0.2 \Omega \mathrm{m})$ downward to another prominent low $(\sim 0.5 \Omega \mathrm{m})$ at 191.7 mbsf. Between 191.7 and 194.78 mbsf, resistivity decreases from 1.45 to $1.18 \Omega$ m with very little fluctuation. From 194.78 to 217.02 mbsf, resistivity exhibits large fluctuations between $<0.8$ and $>1.7 \Omega \mathrm{m}$. From $217.02 \mathrm{mbsf}$, resistivity fluctuations decrease in amplitude $( \pm 0.3 \Omega \mathrm{m})$ and the general trend decreases. Between 225.9 and 230.9 mbsf, resistivity maintains a constant value of $\sim 1.3 \Omega \mathrm{m}$ before a sharp spike at $230.9 \mathrm{mbsf}(\sim 3.2 \Omega \mathrm{m})$, which corresponds to a sharp drop in gamma ray values (from $\sim 107$ to $\sim 68$ gAPI); this marks the Subunit IBi/ IBii boundary.

Subunit IBii (230.9-292.9 mbsf) is characterized by continuous fluctuations around a resistivity baseline of $\sim 1.5 \Omega \mathrm{m}$, reaching highs of $>3.0 \Omega \mathrm{m}$ and lows of $<0.8 \Omega \mathrm{m}$. Toward the base of Subunit IBii (276.4292.9 mbsf) there is a shift to more resistivity spikes with fewer low-value spikes, which corresponds to an increase in bedding dip (Fig. F4). The base of Subunit IBii (292.9 mbsf) is below a large resistivity spike $(\sim 2 \Omega \mathrm{m})$, where resistivity drops to $\sim 1.3 \Omega \mathrm{m}$.

Through Subunit IBiii (292.9-350.0 mbsf) resistivity exhibits a lower baseline $(\sim 1.3 \Omega \mathrm{m})$ and less frequent fluctuations than the overlying intervals (Fig. F6). Between 293 and 329 mbsf, resistivity gradually increases from 1.3 to $1.6 \Omega \mathrm{m}$. At $330.6 \mathrm{mbsf}$, resistivity increases sharply to $\sim 2.2 \Omega \mathrm{m}$, maintaining higher values to $334.98 \mathrm{mbsf}$, where it drops sharply back to the $\sim 1.3 \Omega \mathrm{m}$ baseline. From $334.98 \mathrm{mbsf}$ to the base of the hole (350 mbsf), resistivity remains $\sim 1.3 \Omega \mathrm{m}$, with local spikes to higher values $(\sim 2.3 \Omega \mathrm{m})$.

\section{Resistivity image analysis}

Shallow, medium, and deep button resistivities were used to generate both statically and dynamically processed images (see "Logging while drilling" in the "Methods" chapter [Strasser et al., 2014a]). Bedding, fractures, faults, and breakouts were interpreted. In the absence of a caliper measurement, the bit diameter was used as the borehole diameter and assumed to be constant (see "Logging while drilling" in the "Methods" chapter [Strasser et al., 2014a]).

\section{Bedding and fractures}

Overall, bedding dips were fairly constant throughout the drilled section, exhibiting a consistent shallow $\left(0^{\circ}-25^{\circ}\right)$ dip angle (Fig. F7), with the exception 
of two intervals (81-83 and 127-168 mbsf) (Fig. F4) that correlate with MTDs observed in core from Hole C0018A (Expedition 333 Scientists, 2012b). Bedding dip direction ranges from west-northwest to southsoutheast but does not exhibit a consistent change with depth. The observed shallow dip angle is in good agreement with core observations made in Hole C0018A (Expedition 333 Scientists, 2012b), although the dip direction is more variable in the images.

Abundant fractures and faults primarily occur in the upper section (Subunit IA), with only local moderate-high angle $\left(50^{\circ}-60^{\circ}\right)$ faults observed below 179.8 mbsf (Fig. F4). There is little consistency in the dip angle or direction of the identified faults and fractures (Fig. F7). The highest abundance of faults and fractures occurs in two intervals (61.5-83 and 127$176 \mathrm{mbsf})$ and are concentrated in the area of highangle bedding (Fig. F4).

The two identified intervals of irregularly oriented high-angle bedding and abundant fractures/faults exhibit a chaotic nature in the resistivity images (Fig. F8) and are interpreted to be chaotic deposits, probably associated with MTDs. The intervals over which the images exhibit this chaotic nature are consistent with the depths of chaotic bedding and slump folds observed in core from Hole C0018A (Expedition 333 Scientists, 2012b). In Hole C0018A, six MTDs (1-6) were identified between the seafloor and $190 \mathrm{mbsf}$ (Expedition 333 Scientists, 2012b). In Hole C0018B, there is clear evidence for two MTDs: MTD A at 61.583.0 mbsf and MTD B at 127.0-176.0 mbsf. The top and base of MTDs A and B are based primarily on the change from high-angle, randomly oriented bedding back to consistently low-angle bedding. MTD B most closely corresponds to MTD 6 defined in core from Hole C0018A (Expedition 333 Scientists, 2012b), but the base cannot be easily distinguished in the resistivity images. It is possible that a region of very conductive horizons (Fig. F9) corresponds to the pyriterich zones observed at the base of MTD 6 in core from Hole C0018A (Expedition 333 Scientists, $2012 b)$. The depth range of MTD A encompasses core-defined MTDs 3, 4, and 5 from Hole C0018A (Expedition 333 Scientists, 2012b); however, given the low contrast between the material in the MTDs and the background hemipelagic sediment, the resistivity images do not allow separating individual MTDs within this interval. Other core-defined MTDs ( 1 and 2) from Hole C0018A are at shallower depths than covered by the resistivity images, but a possible basal surface of a disturbed interval observed at 48.0 mbsf, just below the start of the images, suggests the presence of another MTD.

\section{Borehole breakouts}

Borehole breakout analysis was performed to assess the orientation of the maximum horizontal stress direction within the borehole. Breakouts appear as two vertical conductive zones, with $180^{\circ}$ of separation between them. Breakouts typically form perpendicular to the direction of maximum horizontal stress $\left(S_{\text {HMAX }}\right)$ in the borehole. Breakout width can be related to the horizontal differential stress (e.g., Chang et al., 2010). In Hole C0018B, the depth intervals immediately following a pipe connection, indicated by time-after-bit measurements, show significantly wider breakouts than the rest of the formation, particularly in the upper section (Fig. F4). This could be due to time-dependent evolution of pore pressure (e.g., Moore et al., 2011) or changes in annular pressure during pipe connections. These ideas will be explored further in postcruise research.

In Hole C0018B, few breakouts are observed in the upper section, with the exception of those breakouts immediately following pipe connections. Breakout occurrence increases with depth, and breakouts are most prevalent in the lower section of logging Subunit IB (Fig. F4). Analyses indicate a mean azimuth of $51^{\circ}$ and, therefore, an azimuth of $141^{\circ}$ for $S_{\text {HMAX }}$. This northwest-southeast trend is roughly parallel to the convergent direction of the Philippine Sea plate and to the dominant $S_{\text {HMAX }}$ determined at previous IODP Nankai Trough Seismogenic Zone Experiment (NanTroSEIZE) Sites C0001, C0004, C0006, and C0009 (Chang et al., 2010; Lin et al., 2010; Byrne et al., 2009; Kinoshita et al., 2008) and Ocean Drilling Program Site 808 (Ienaga et al., 2006; McNeill et al., 2004).

\section{Physical properties}

\section{Estimation of porosity and bulk density} from resistivity

We estimated porosity using Archie's law (Archie, 1947) (see the "Methods" chapter [Strasser et al., 2014a]) and calculated seawater electrical resistivity using the temperature profile that was estimated for Site C0018 during Expedition 333. The temperature at the seafloor is estimated at $1.48^{\circ} \mathrm{C}$, with an average thermal gradient of $63^{\circ} \mathrm{C} / \mathrm{km}$ (Expedition 333 Scientists, 2012b). Archie's law parameters were found by fitting the Archie equation to resistivity measurements (conducted at $2 \mathrm{kHz}$ ) and moisture and density (MAD)-derived porosity measurements taken during Expedition 333 on sediment recovered from Hole C0018A (Expedition 333 Scientists, $2012 \mathrm{~b})$. The parameters that best fit the data are $a=$ 1.72 and $m=1.68$, with a coefficient of determina- 
tion $\left(R^{2}\right)$ of 0.50 . Archie's law with the parameters estimated based on density and resistivity logs at IODP Site C0002 during Expedition 314, $a=1$ and $m=2.4$ (Expedition 314 Scientists, 2009; see the "Site C0002" chapter [Strasser et al., 2014b]), is shown for comparison in Figure F10. Note that $R^{2}=0.29$ for the Site $\mathrm{C} 0002$ parameters. The parameters estimated from the Hole C0018A data are applied to the entire drilled section of Hole C0018B; thus, the values of $a$ and $m$ do not account for lithologic variations with depth and may be affected by the presence of the MTDs. Additionally, a value of $a \neq 1$ may indicate that a clayey formation rock matrix is conducting electricity (Glover et al., 2000). In this case, Archie's law would not be appropriate to describe the electrical resistivity and MAD-derived porosity measurements taken during Expedition 333. Bulk density was estimated from the resistivity-derived porosity using a grain density $\left(\rho_{\mathrm{g}}\right)$ value of $2.66 \mathrm{~g} / \mathrm{cm}^{3}$. This grain density value is an average, with a standard deviation of $0.10 \mathrm{~g} / \mathrm{cm}^{3}$, of all of the MAD-derived grain densities measured during Expedition 333 (Expedition 333 Scientists, 2012b).

The resistivity-derived porosity and bulk density depth trends are shown in Figure F4. Porosity values are very high in the upper $20 \mathrm{~m}$ of the hole, decreasing from $>95 \%$ at the seafloor to $73 \%$ at 20 mbsf; these large values reflect bit resistivity measurements that are very close (less than a factor of 2 larger) to the estimated values of seawater resistivity. Below 20 mbsf, there is some scatter in the resistivity-derived porosity values, but porosity decreases in a generally linear fashion to $51 \%$ at the base of Subunit IA (0179.8 mbsf). There are several prominent spikes in the porosity values within Subunit IBi (179.8-230.9 mbsf). Within the upper $3 \mathrm{~m}$ of Subunit IBi, porosity spikes to $93 \%$ (179.8 mbsf), 72\% (181.8 mbsf), and $63 \%$ (182.7 mbsf), decreasing to $\sim 50 \%$. There are spikes to $66 \%$ (191.6 mbsf) and 63\% (206.2 mbsf), below which the porosity decreases to $43 \%$ at the base of Subunit IBi (230.9 mbsf). Porosity increases to $48 \%$ near the top of Subunit IBii (230.9-292.9 mbsf). Within Subunit IBii, porosity values are scattered but generally decrease to $40 \%$ at the base of the unit (292.9 mbsf). Within Subunit IBiii, porosity increases to $47 \%$ (293.4 mbsf) before decreasing to $37 \%$ at 334.7 mbsf. Resistivity-derived porosity increases to $44 \%$ at $337.3 \mathrm{mbsf}$ and remains relatively constant through to the base of Hole C0018B (350.0 mbsf).

Trends in resistivity-derived bulk density mirror those described above for the resistivity-derived porosity because reported bulk density values are a mathematical manipulation of the derived porosity values (Fig. F4). Generally, bulk density increases from $\sim 1 \mathrm{~g} / \mathrm{cm}^{3}$ at the seafloor to $1.8 \mathrm{~g} / \mathrm{cm}^{3}$ at the base of Subunit IA (179.8 mbsf). Bulk density values decrease to $1.1 \mathrm{~g} / \mathrm{cm}^{3}$ at the top of Subunit IBi before generally increasing to $1.9 \mathrm{~g} / \mathrm{cm}^{3}$ at the base of Subunit IBi (230.9 mbsf). Several large decreases in the estimated bulk density values within Subunit IBi are coincident with the porosity spikes noted above. Bulk density generally increases to $2.0 \mathrm{~g} / \mathrm{cm}^{3}$ at the base of Subunit IBii (292.2 mbsf) then drops to 1.9 $\mathrm{g} / \mathrm{cm}^{3}$ near the top of Subunit IBiii before increasing to $2.1 \mathrm{~g} / \mathrm{cm}^{3}$ at $334.7 \mathrm{mbsf}$, decreasing to $1.95 \mathrm{~g} / \mathrm{cm}^{3}$ at $337.3 \mathrm{mbsf}$, and remaining generally constant to the bottom of the hole ( $350.0 \mathrm{mbsf})$.

Figure F11 shows the resistivity-derived porosity and bulk density logs plotted for comparison along with MAD-derived measurements taken during Expedition 333 (Expedition 333 Scientists, 2012b). The resistivity-derived porosity values are noticeably higher than the MAD-derived values in the upper $80 \mathrm{~m}$ of Site C0018. The offset $\Delta \phi=\phi_{\mathrm{MAD}}-\phi_{\text {resistivity }}$ is greatest at the seafloor $(\Delta \phi=-0.4)$ but decreases steadily, becoming $\sim 0$ by 80 mbsf. The resistivityand MAD-derived values maintain a good agreement from 80 mbsf to the bottom of Hole C0018B. For further comparison, a resistivity-derived porosity log using the Archie parameters from Site C0002 is also shown. This porosity log maintains a good agreement with the MAD-derived porosity measurements throughout the hole, although the Archie parameters from Site C0002 produce a poor fit to the relationship between MAD porosity and resistivity that were measured on cores during Expedition 333 in Hole C0018A (Fig. F10 and discussion above).

\section{Core-log-seismic integration}

Hole C0018B is located $25 \mathrm{~m}$ north-northwest of Hole C0018A (Expedition 333 Scientists, 2012a). Site C0018 is the primary site proposed in the Nankai Trough Submarine Landslide History ancillary project letter to investigate MTDs within the shallow slope cover of the Nankai accretionary prism (Strasser et al., 2011, 2012). Cores recovered from Hole C0018A during Expedition 333 (Expedition 333 Scientists, 2012a) provided detailed lithologic information for the slope cover sedimentary sequence and intercalated MTDs from 0 to 314 mbsf. LWD to 350 mbsf was added during Expedition 338, providing new data for characterizing in situ internal structure and properties of MTDs and for core-log-seismic integration. 
The Kumano 3-D prestack depth migration (PSDM) seismic volume (Moore et al., 2009) ties to Site C0018 at the intersection of In-line 2315 and Crossline 4950. A prominent seismic reflection was identified as the boundary between two lithologic/logging subunits of differing seismic character, defined by Kimura et al. (2011) and Strasser et al. (2011) as seismic Subunits IA and IB. The correlative two subunits were also identified at Site C0018 following analysis of the core and LWD data from Holes C0018A and C0018B, respectively. Figure F12 presents an overview of the correlation between the LWD, seismic, and core data.

Seismic Subunit IA is characterized by several packages (generally $<100 \mathrm{~m}$ thick) of chaotic, low-amplitude reflectivity. These packages were originally discovered from analysis of the seismic data in the region of scarps identified in the high-resolution bathymetry data and are interpreted as MTDs (Strasser et al., 2011).

The dominant lithology of lithologic Subunit IA is greenish-gray silty clay. Variability in the abundance of volcanic ash was used to further divide this subunit into individual facies (Expedition 333 Scientists, 2012b). Analysis of X-ray computed tomography images and structural measurements highlighted a number of contorted, folded sections, providing evidence for a total of six intervals with characteristics of MTDs, the largest being an $\sim 60 \mathrm{~m}$ interval from 128 to 188 mbsf (Fig. F12).

Resistivity images of logging Subunit IA (Fig. F12) corroborate observations from the core and seismic data. Generally, bedding dip angles were found to be low to moderate $\left(<20^{\circ}\right)$ except for two intervals that displayed high-angle $\left(>60^{\circ}\right)$ bedding surfaces (many nonplanar) with variable dip direction, indicative of large-scale deformation. The upper interval (61.5$83.0 \mathrm{mbsf}$ ) only had a few clear bedding planes at its base, with its upper surface defined by the disappearance of coincident high-angle fractures and the reappearance of low-angle $\left(<10^{\circ}\right)$ bedding planes. The lower interval (127-176 mbsf) is more clearly defined, with high-angle bedding surfaces throughout. These two intervals correspond to the locations of the two largest MTDs (5 and 6) that were identified from cores.

Although both intervals correlate with the core and seismic data and are therefore identified as MTDs, they display different characteristics in resistivity. The upper MTD (5) has a low and relatively constant resistivity of $\sim 1.0 \Omega \mathrm{m}$, whereas resistivity in the lower MTD (6) shows an overall increase with depth but fluctuates between 0.5 and $1.5 \Omega \mathrm{m}$ (Fig. F12). The higher variability in resistivity of the lower MTD might have resulted from a larger amount of internal deformation during transport, occurring as a function of its larger size and greater transport distance.

A positive seismic reflection correlates to the base of MTD 6 at 188.5 mbsf in Hole C0018A, defined by a thick volcaniclastic sand layer, and also ties well with the change to sand-dominated lithology documented in cores (i.e., Subunit IA/IB boundary). The base of logging Subunit IA was picked at the slightly shallower depth of 179.8 mbsf based on the departure of the resistivity curve to lower values and an increase in its short wavelength variability (Fig. F12).

However, there is contrasting evidence from the gamma ray curve for distinct sand packages below $\sim 205$ mbsf (Fig. F12), which may correlate to the first downhole occurrence of Subunit IB sand layers in Hole C0018B. Thus, correlation of the Subunit IA/IB boundary between Holes C0018A and C0018B is not fully conclusive. The mismatch could be explained by the distinct geometry of the MTD. Interpretations of the 3-D seismic volume show that this MTD had a south-southwest flow direction with lateral ramps that developed near Site C0018 (Strasser et al., 2011). The short lateral offset between holes may lead to Hole C0018A being situated on the southeast edge of the deposit and Hole C0018B being located within the main flow area, where the basal part of the MTD would represent eroded or off-scraped material incorporated into the MTD. For further discussion on regional correlation of the base of MTD 6, see "Corelog-seismic integration" in the "Site C0021" chapter (Strasser et al., 2014c).

Lithologic Subunit IB comprises interbedded finegrained to medium sand, silty sand, silty clay, and clay (Expedition 333 Scientists, 2012b). Distinct sand layers are not distinguishable in logging data, and overall, the gamma ray values for logging Subunit IB follow a higher baseline (85 gAPI) compared to logging Subunit IA (75 gAPI) with only a few clear spikes to lower gamma ray values ( $<60$ gAPI; see "Logging while drilling"). The mismatch between core lithology and LWD data characteristics may occur because the thin sand layers $(4-20 \mathrm{~cm})$ are significantly smaller than the vertical resolution of the gamma ray tool $(\sim 30 \mathrm{~cm}$, see the "Methods" chapter [Strasser et al., 2014a]), so the dominant signal is that of the muddy sediment, which locally is as thick as $4 \mathrm{~m}$ (Expedition 333 Scientists, 2012b).

Further subdivision of logging units was based on the resistivity data, which show two breaks in the overall high variability at $\sim 231$ and $\sim 293$ mbsf. Although there is no clear tie between these boundaries and the core lithology, it is possible that they correlate with reflections in the seismic data at these 
depths (Fig. F12). A third reflection at $\sim 265 \mathrm{mbsf}$ may also correlate with reduced variability in resistivity.

\section{References}

Archie, G.E., 1947. Electrical resistivity-an aid in core analysis interpretation. AAPG Bull., 31(2):350-366.

Byrne, T.B., Lin, W., Tsutsumi, A., Yamamoto, Y., Lewis, J.C., Kanagawa, K., Kitamura, Y., Yamaguchi, A., and Kimura, G., 2009. Anelastic strain recovery reveals extension across SW Japan subduction zone. Geophys. Res. Lett., 36(23):L23310. doi:10.1029/2009GL040749

Chang, C., McNeill, L.C., Moore, J.C., Lin, W., Conin, M., and Yamada, Y., 2010. In situ stress state in the Nankai accretionary wedge estimated from borehole wall failures. Geochem., Geophys., Geosyst., 11:Q0AD04. doi:10.1029/2010GC003261

Expedition 314 Scientists, 2009. Expedition 314 Site C0002. In Kinoshita, M., Tobin, H., Ashi, J., Kimura, G., Lallemant, S., Screaton, E.J., Curewitz, D., Masago, H., Moe, K.T., and the Expedition 314/315/316 Scientists, Proc. IODP, 314/315/316: Washington, DC (Integrated Ocean Drilling Program Management International, Inc.). doi:10.2204/iodp.proc.314315316.114.2009

Expedition 333 Scientists, 2012a. Expedition 333 summary. In Henry, P., Kanamatsu, T., Moe, K., and the Expedition 333 Scientists, Proc. IODP, 333: Tokyo (Integrated Ocean Drilling Program Management International, Inc.). doi:10.2204/iodp.proc.333.101.2012

Expedition 333 Scientists, 2012b. Site C0018. In Henry, P., Kanamatsu, T., Moe, K., and the Expedition 333 Scientists, Proc. IODP, 333: Tokyo (Integrated Ocean Drilling Program Management International, Inc.). doi:10.2204/iodp.proc.333.103.2012

Glover, P.W.J., Hole, M.J., and Pous, J., 2000. A modified Archie's law for two conducting phases. Earth Planet. Sci. Lett., 180(3-4):369-383. doi:10.1016/S0012$821 \mathrm{X}(00) 00168-0$

Heki, K., 2007. Secular, transient, and seasonal crustal movements in Japan from a dense GPS array: implication for plate dynamics in convergent boundaries. In Dixon, T.H., and Moore, J.C. (Eds.), The Seismogenic Zone of Subduction Thrust Faults: New York (Columbia Univ. Press), 512-539.

Ienaga, M., McNeill, L.C., Mikada, H., Saito, S., Goldberg, D., and Moore, J.C., 2006. Borehole image analysis of the Nankai accretionary wedge, ODP Leg 196: structural and stress studies. Tectonophysics, 426(1-2):207-220. doi:10.1016/j.tecto.2006.02.018

Kimura, G., Moore, G.F., Strasser, M., Screaton, E., Curewitz, D., Streiff, C., and Tobin, H., 2011. Spatial and temporal evolution of the megasplay fault in the Nankai Trough. Geochem., Geophys., Geosyst., 12(3):Q0A008. doi:10.1029/2010GC003335

Kinoshita, M., Tobin, H., Moe, K.T., and the Expedition 314 Scientists, 2008. NanTroSEIZE Stage 1A: NanTro-
SEIZE LWD transect. IODP Prel. Rept., 314. doi:10.2204/ iodp.pr.314.2008

Lin, W., Doan, M.-L., Moore, J.C., McNeill, L., Byrne, T.B., Ito, T., Saffer, D., Conin, M., Kinoshita, M., Sanada, Y., Moe, K.T., Araki, E., Tobin, H., Boutt, D., Kano, Y., Hayman, N.W., Flemings, P., Huftile, G.J., Cukur, D., Buret, C., Schleicher, A.M., Efimenko, N., Kawabata, K., Buchs, D.M., Jiang, S., Kameo, K., Horiguchi, K., Wiersberg, T., Kopf, A., Kitada, K., Eguchi, N., Toczko, S., Takahashi, K., and Kido, Y., 2010. Present-day principal horizontal stress orientations in the Kumano forearc basin of the southwest Japan subduction zone determined from IODP NanTroSEIZE drilling Site C0009. Geophys. Res. Lett., 37:L13303. doi:10.1029/2010GL043158

McNeill, L.C., Ienaga, M., Tobin, H., Saito, S., Goldberg, D., Moore, J.C., and Mikada, H., 2004. Deformation and in situ stress in the Nankai accretionary prism from resistivity-at-bit images, ODP Leg 196. Geophys. Res. Lett., 31(2):L02602. doi:10.1029/2003GL018799

Moore, G.F., Park, J.-O., Bangs, N.L., Gulick, S.P., Tobin, H.J., Nakamura, Y., Sato, S., Tsuji, T., Yoro, T., Tanaka, H., Uraki, S., Kido, Y., Sanada, Y., Kuramoto, S., and Taira, A., 2009. Structural and seismic stratigraphic framework of the NanTroSEIZE Stage 1 transect. In Kinoshita, M., Tobin, H., Ashi, J., Kimura, G., Lallemant, S., Screaton, E.J., Curewitz, D., Masago, H., Moe, K.T., and the Expedition 314/315/316 Scientists, Proc. IODP, 314/315/316: Washington, DC (Integrated Ocean Drilling Program Management International, Inc.). doi:10.2204/iodp.proc.314315316.102.2009

Moore, J.C., Chang, C., McNeill, L., Moe, K.T., Yamada, Y., and Huftile, G., 2011. Growth of borehole breakouts with time after drilling: implications for state of stress, NanTroSEIZE transect, SW Japan. Geochem., Geophys., Geosyst., 12(4). doi:10.1029/2010GC003417

Screaton, E.J., Kimura, G., Curewitz, D., and the Expedition 316 Scientists, 2009. Expedition 316 summary. In Kinoshita, M., Tobin, H., Ashi, J., Kimura, G., Lallemant, S., Screaton, E.J., Curewitz, D., Masago, H., Moe, K.T., and the Expedition 314/315/316 Scientists, Proc. IODP, 314/315/316: Washington, DC (Integrated Ocean Drilling Program Management International, Inc.). doi:10.2204/iodp.proc.314315316.131.2009

Seno, T., Stein, S., and Gripp, A.E., 1993. A model for the motion of the Philippine Sea plate consistent with NUVEL-1 and geological data. J. Geophys. Res.: Solid Earth, 98(B10):17941-17948. doi:10.1029/93JB00782

Strasser, M., Dugan, B., Kanagawa, K., Moore, G.F., Toczko, S., Maeda, L., Kido, Y., Moe, K.T., Sanada, Y., Esteban, L., Fabbri, O., Geersen, J., Hammerschmidt, S., Hayashi, H., Heirman, K., Hüpers, A., Jurado Rodriguez, M.J., Kameo, K., Kanamatsu, T., Kitajima, H., Masuda, H., Milliken, K., Mishra, R., Motoyama, I., Olcott, K., Oohashi, K., Pickering, K.T., Ramirez, S.G., Rashid, H., Sawyer, D., Schleicher, A., Shan, Y., Skarbek, R., Song, I., Takeshita, T., Toki, T., Tudge, J., Webb, S., Wilson, D.J., Wu, H.-Y., and Yamaguchi, A., 2014a. Methods. In Strasser, M., Dugan, B., Kanagawa, K., Moore, G.F., Toczko, S., Maeda, L., and the Expedition 338 Scientists, Proc. IODP, 
338: Yokohama (Integrated Ocean Drilling Program). doi:10.2204/iodp.proc.338.102.2014

Strasser, M., Dugan, B., Kanagawa, K., Moore, G.F., Toczko, S., Maeda, L., Kido, Y., Moe, K.T., Sanada, Y., Esteban, L., Fabbri, O., Geersen, J., Hammerschmidt, S., Hayashi, H., Heirman, K., Hüpers, A., Jurado Rodriguez, M.J., Kameo, K., Kanamatsu, T., Kitajima, H., Masuda, H., Milliken, K., Mishra, R., Motoyama, I., Olcott, K., Oohashi, K., Pickering, K.T., Ramirez, S.G., Rashid, H., Sawyer, D., Schleicher, A., Shan, Y., Skarbek, R., Song, I., Takeshita, T., Toki, T., Tudge, J., Webb, S., Wilson, D.J., Wu, H.-Y., and Yamaguchi, A., 2014b. Site C0002. In Strasser, M., Dugan, B., Kanagawa, K., Moore, G.F., Toczko, S., Maeda, L., and the Expedition 338 Scientists, Proc. IODP, 338: Yokohama (Integrated Ocean Drilling Program). doi:10.2204/iodp.proc.338.103.2014

Strasser, M., Dugan, B., Kanagawa, K., Moore, G.F., Toczko, S., Maeda, L., Kido, Y., Moe, K.T., Sanada, Y., Esteban, L., Fabbri, O., Geersen, J., Hammerschmidt, S., Hayashi, H., Heirman, K., Hüpers, A., Jurado Rodriguez, M.J., Kameo, K., Kanamatsu, T., Kitajima, H., Masuda, H., Milliken, K., Mishra, R., Motoyama, I., Olcott, K., Oohashi, K., Pickering, K.T., Ramirez, S.G., Rashid, H., Sawyer, D., Schleicher, A., Shan, Y., Skarbek, R., Song, I., Takeshita,
T., Toki, T., Tudge, J., Webb, S., Wilson, D.J., Wu, H.-Y., and Yamaguchi, A., 2014c. Site C0021. In Strasser, M., Dugan, B., Kanagawa, K., Moore, G.F., Toczko, S., Maeda, L., and the Expedition 338 Scientists, Proc. IODP, 338: Yokohama (Integrated Ocean Drilling Program). doi:10.2204/iodp.proc.338.106.2014

Strasser, M., Henry, P., Kanamatsu, T., Moe, K.T., Moore, G.F., and the IODP Expedition 333 Scientists, 2012. Scientific drilling of mass-transport deposits in the Nankai accretionary wedge: first results from IODP Expedition 333. In Yamada, Y., Kawamura, K., Ikehara, K., Ogawa, Y., Urgeles, R., Mosher, D., Chaytor, J., and Strasser, M. (Eds.), Submarine Mass Movements and Their Consequences. Adv. Nat. Technol. Hazard Res., 31(8):671-681. doi:10.1007/978-94-007-2162-3_60

Strasser, M., Moore, G.F., Kimura, G., Kopf, A.J., Underwood, M.B., Guo, J., and Screaton, E.J., 2011. Slumping and mass-transport deposition in the Nankai forearc: evidence from IODP drilling and 3-D reflection seismic data. Geochem., Geophys., Geosyst., 12:Q0AD13. doi:10.1029/2010GC003431

Publication: 13 January 2014 MS 338-105 
Figure F1. Regional location map showing Site C0018 in context of NanTroSEIZE project sites. Box $=$ region with 3-D seismic data, red $=$ Expedition 338 sites, blue $=$ NanTroSEIZE Stage 1 and 2 sites, yellow arrows $=$ estimated far-field vectors between Philippine Sea plate and Japan (Seno et al., 1993; Heki, 2007), stars = locations of 1944 and 1946 tsunamigenic earthquakes.

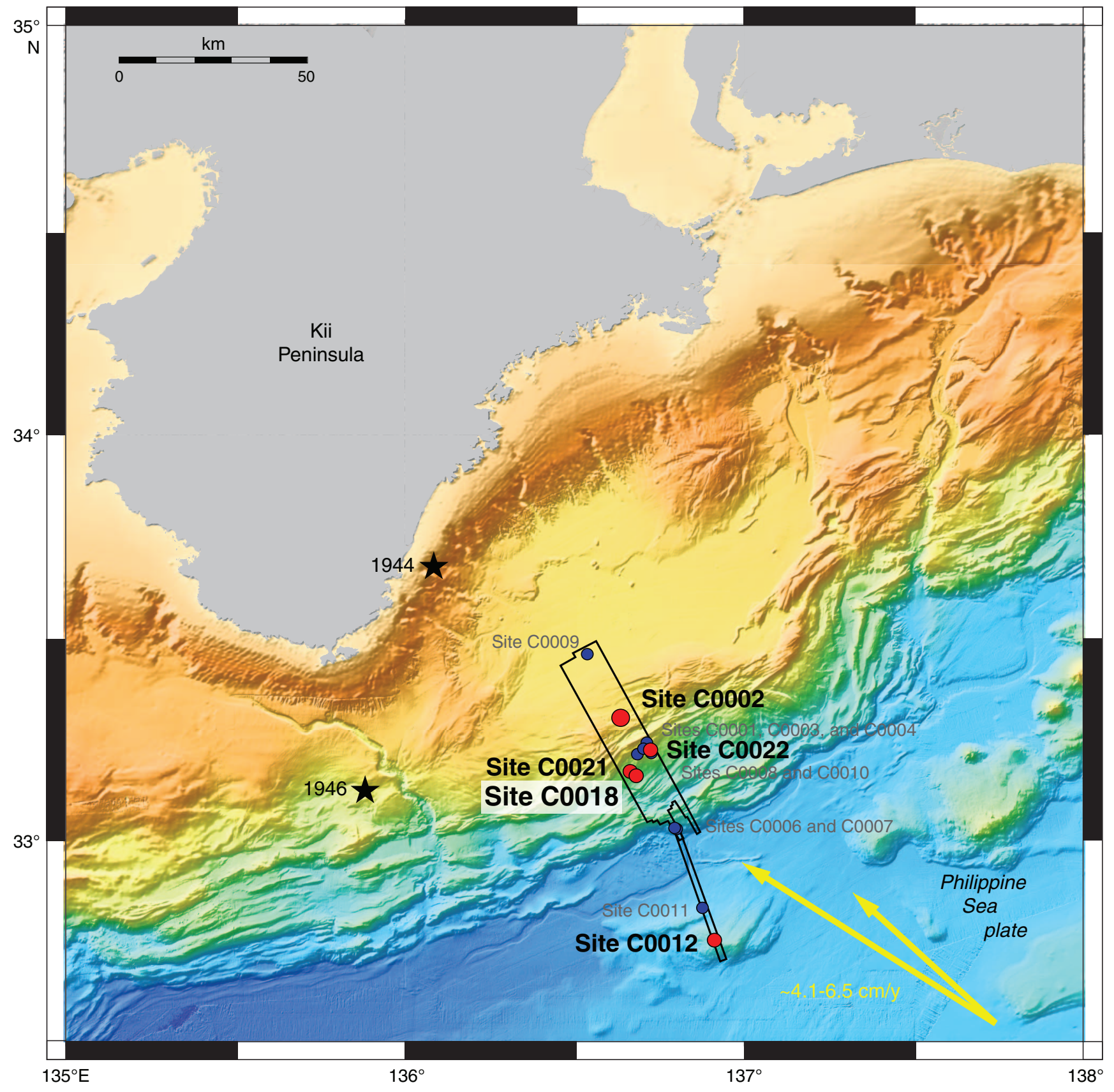


Figure F2. Block diagram with detailed bathymetry and interpreted structure around Site C0018 at the footwall of the splay fault together with adjacent drill sites (Strasser et al., 2011). Multichannel seismic in-line (IL) and cross-line (XL) over Site C0018. VE = vertical exaggeration.
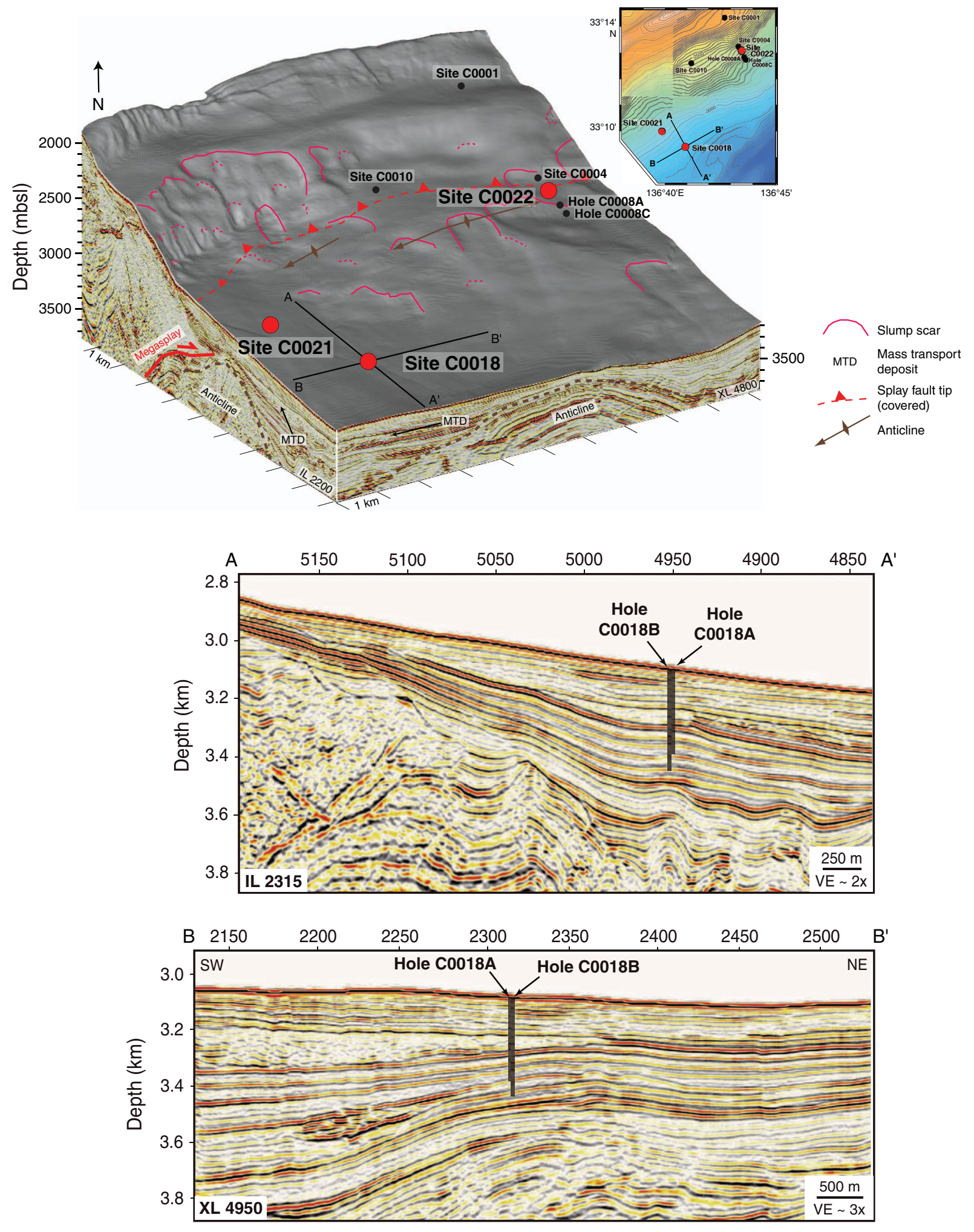
Figure F3. Sedimentary log for Hole C0018A, showing interpreted units and facies, recovery rates, stratigraphy, and depths of drilled intervals with mass transport deposits (MTDs) (Expedition 333 Scientists, 2012a). FO = first occurrence, $\mathrm{LO}=$ last occurrence, $\mathrm{LCO}=$ last common occurrence, $\mathrm{FCO}=$ first common occurrence.

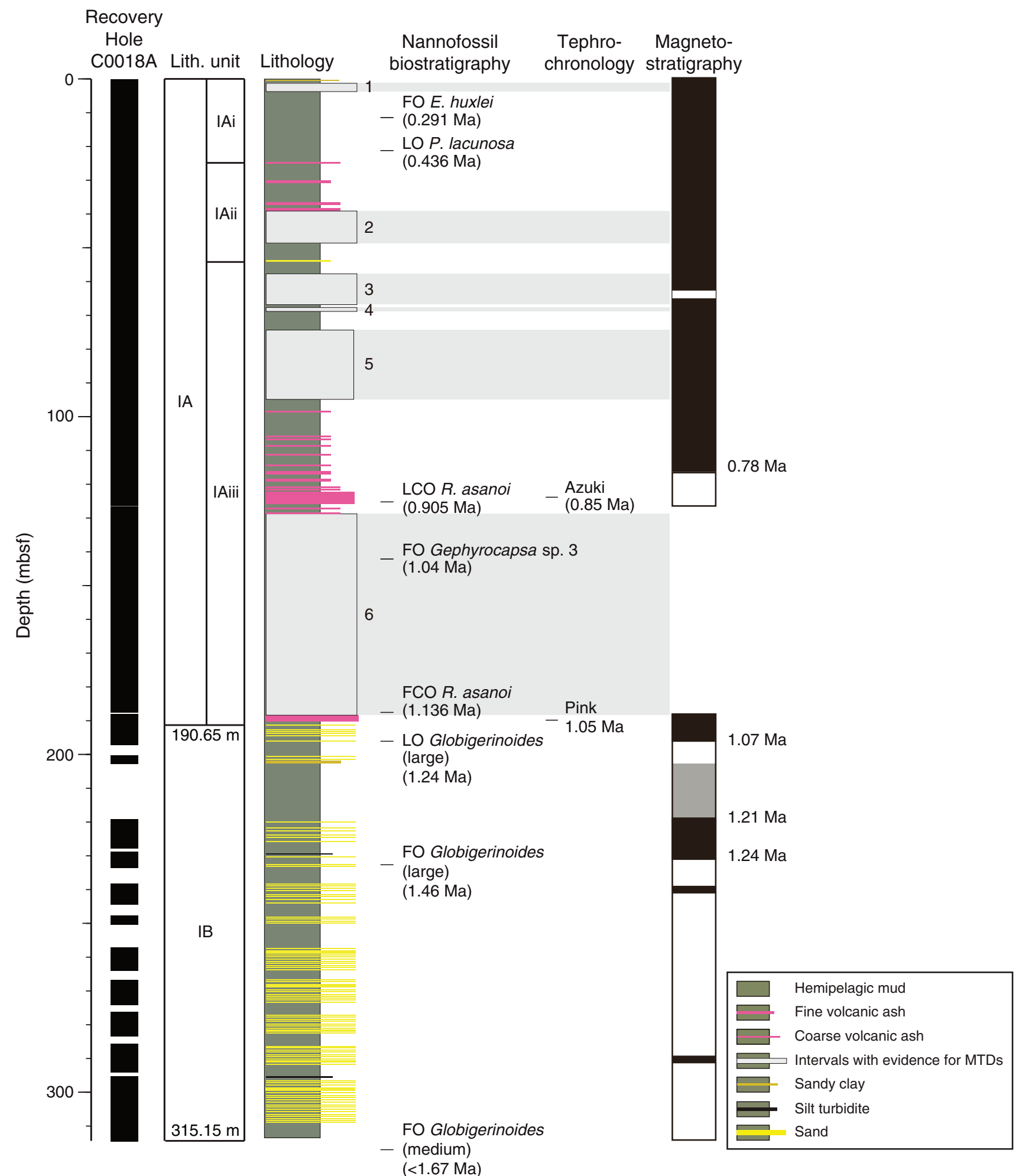


Figure F4. Overview composite plot of LWD data and deep resistivity image for Hole C0018B, with logging units, resistivity-derived porosity based on Archie parameters from Expedition 314 Hole C0002A LWD (red) and Expedition 333 Hole C0018A cores (blue), resistivity-derived bulk density, and bedding and fracture dips.
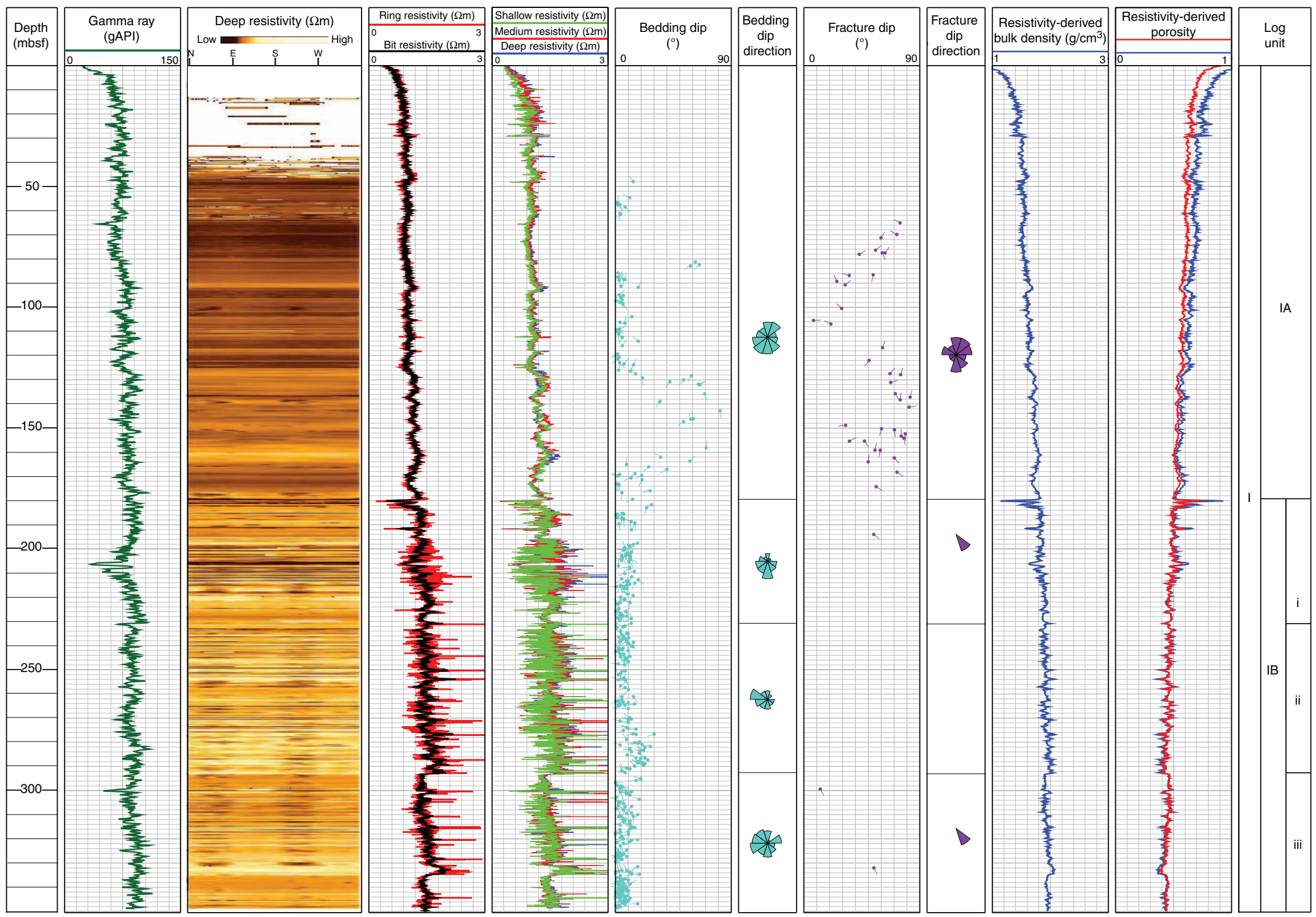
Figure F5. Composite plot of gamma ray and resistivity logs through logging Subunit IA in Hole C0018B, with observed trends (black arrows) and spikes (red arrows) highlighted.

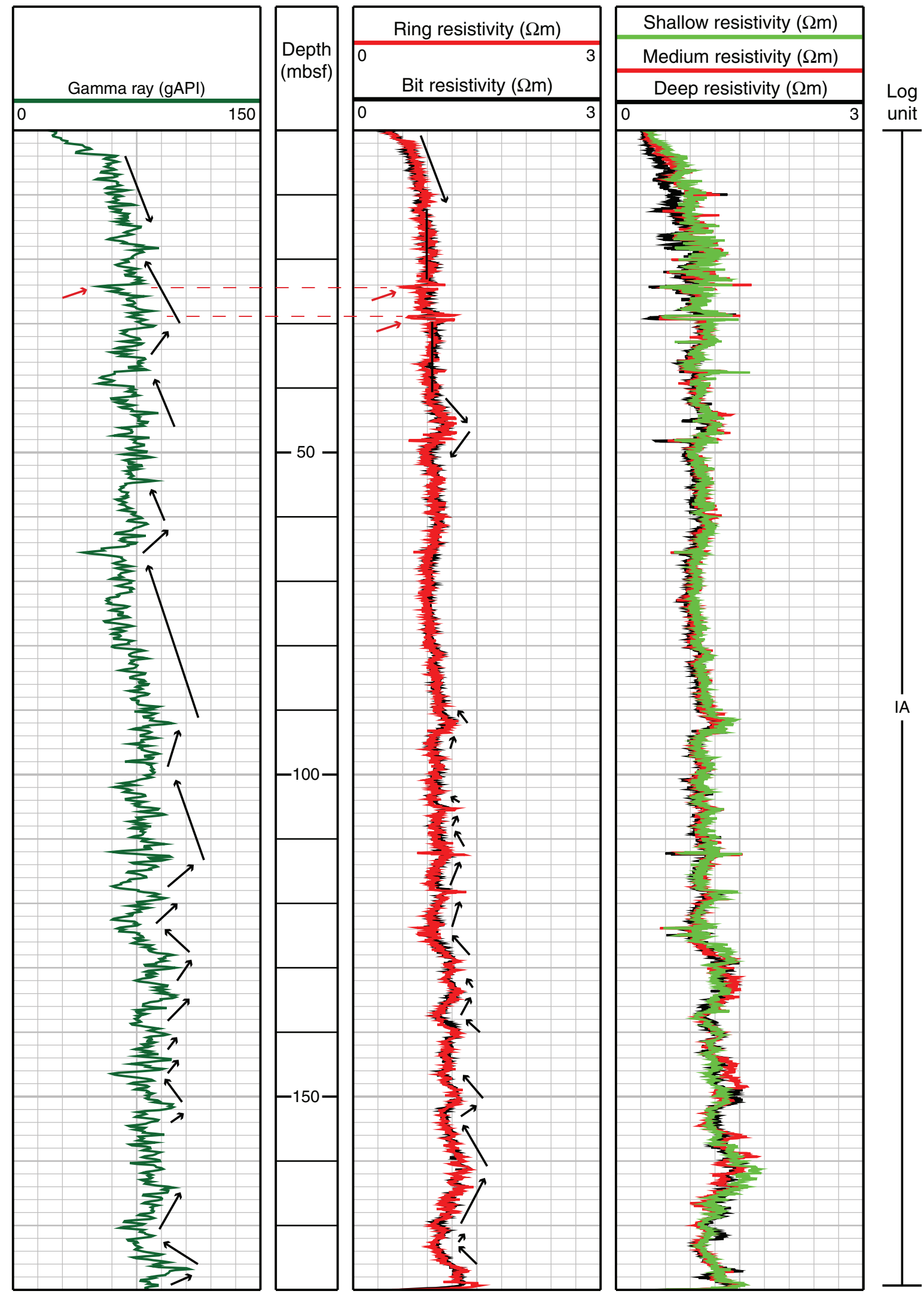


Figure F6. Composite plot of gamma ray and resistivity logs through logging Subunit IB in Hole C0018B, with observed trends (black arrows) and spikes (red arrows) highlighted.

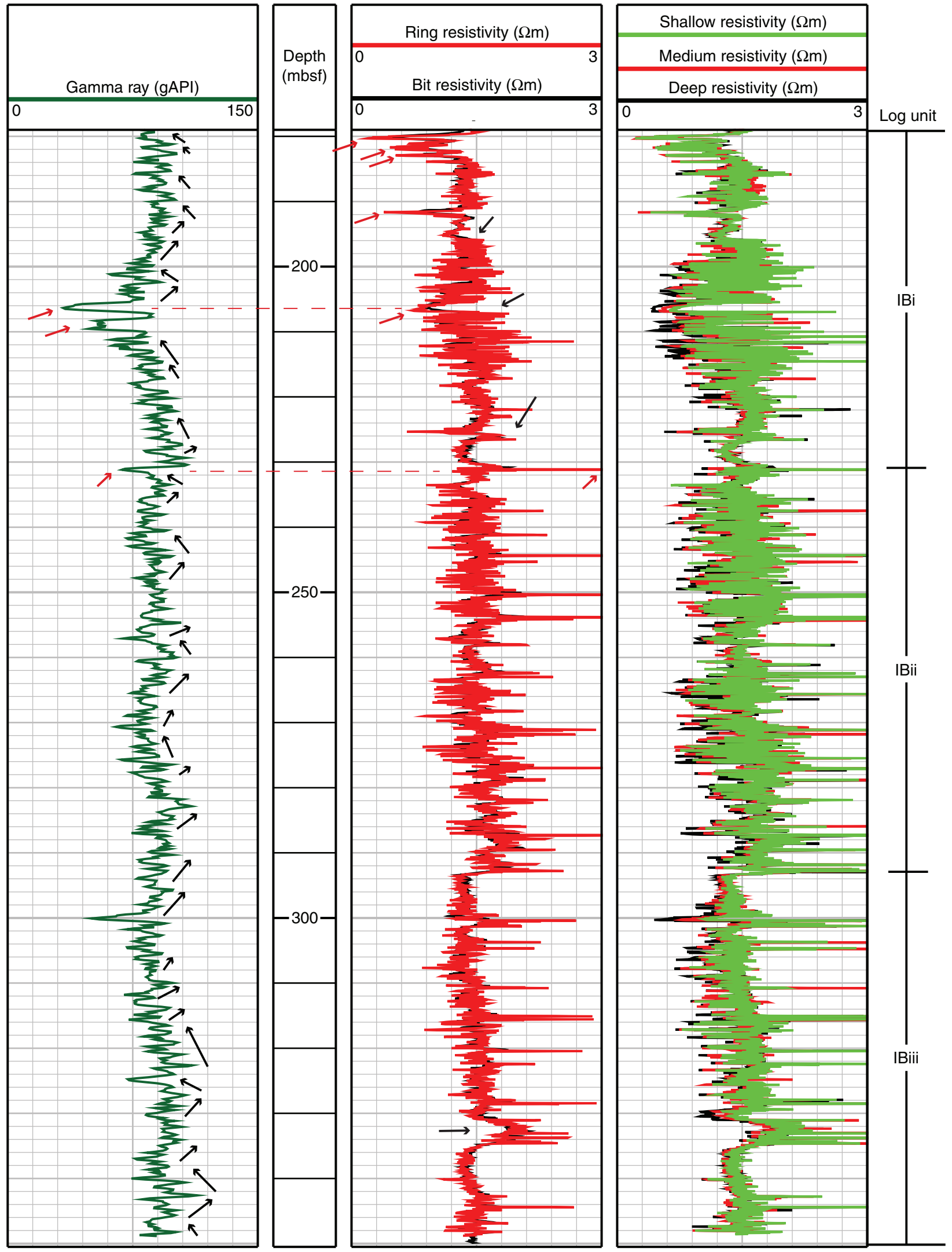


Figure F7. Rose diagrams of the dip and azimuth of fractures and bedding, Hole C0018B. Stereonets are lowerhemisphere projections of poles to planes, Hole C0018B.

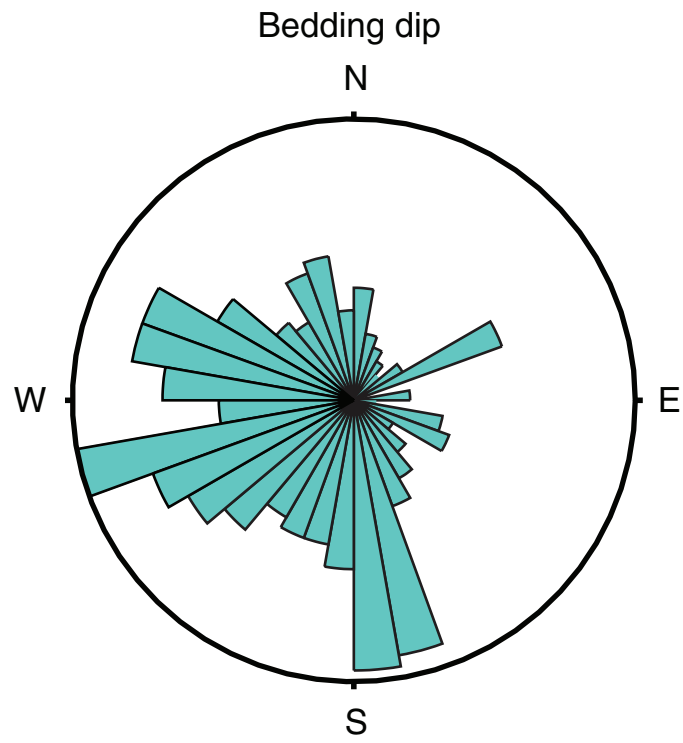

Fracture dip
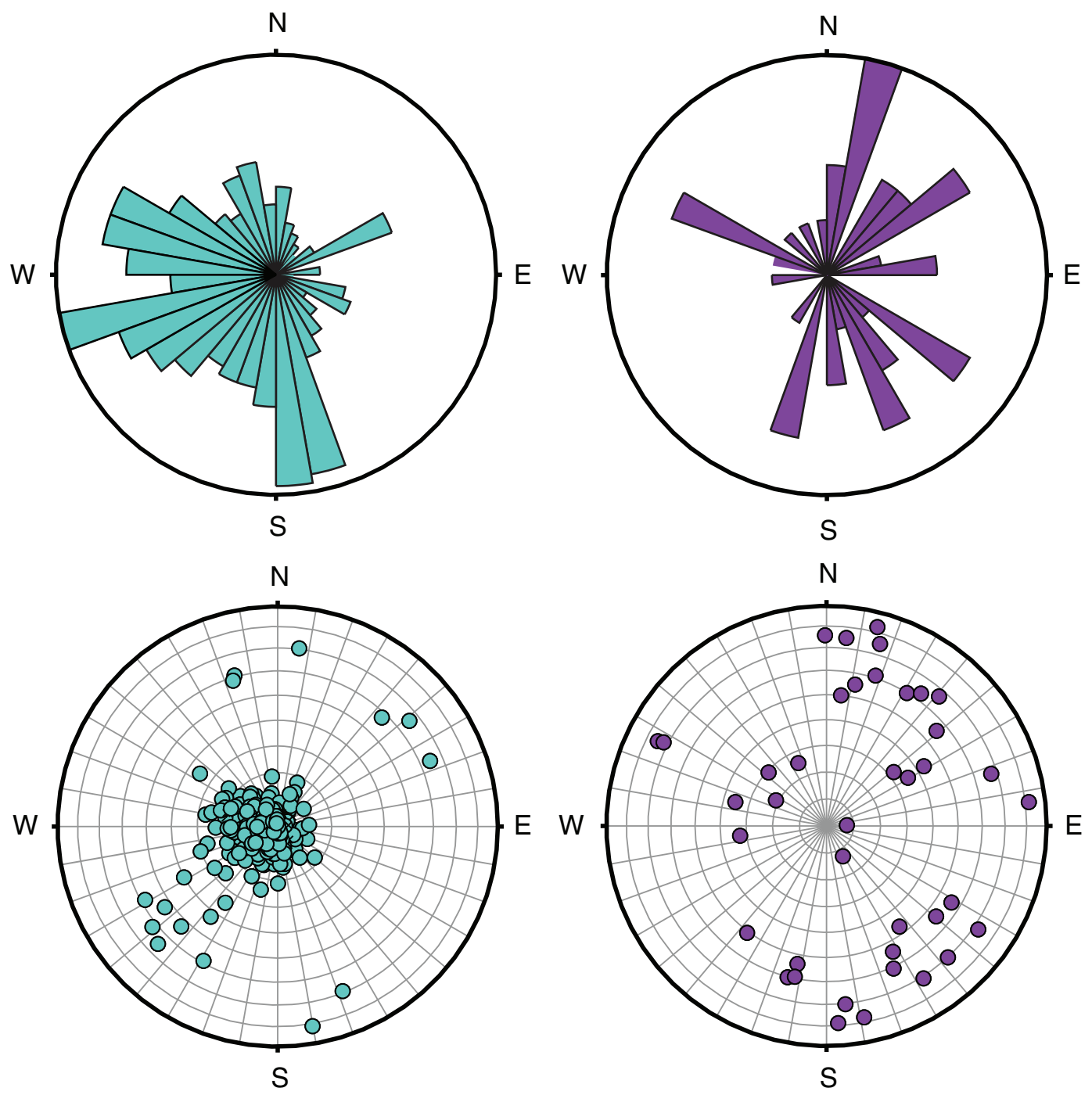
Figure F8. Static and dynamic processed images through mass transport deposits (MTDs) A and B, Hole C0018B.
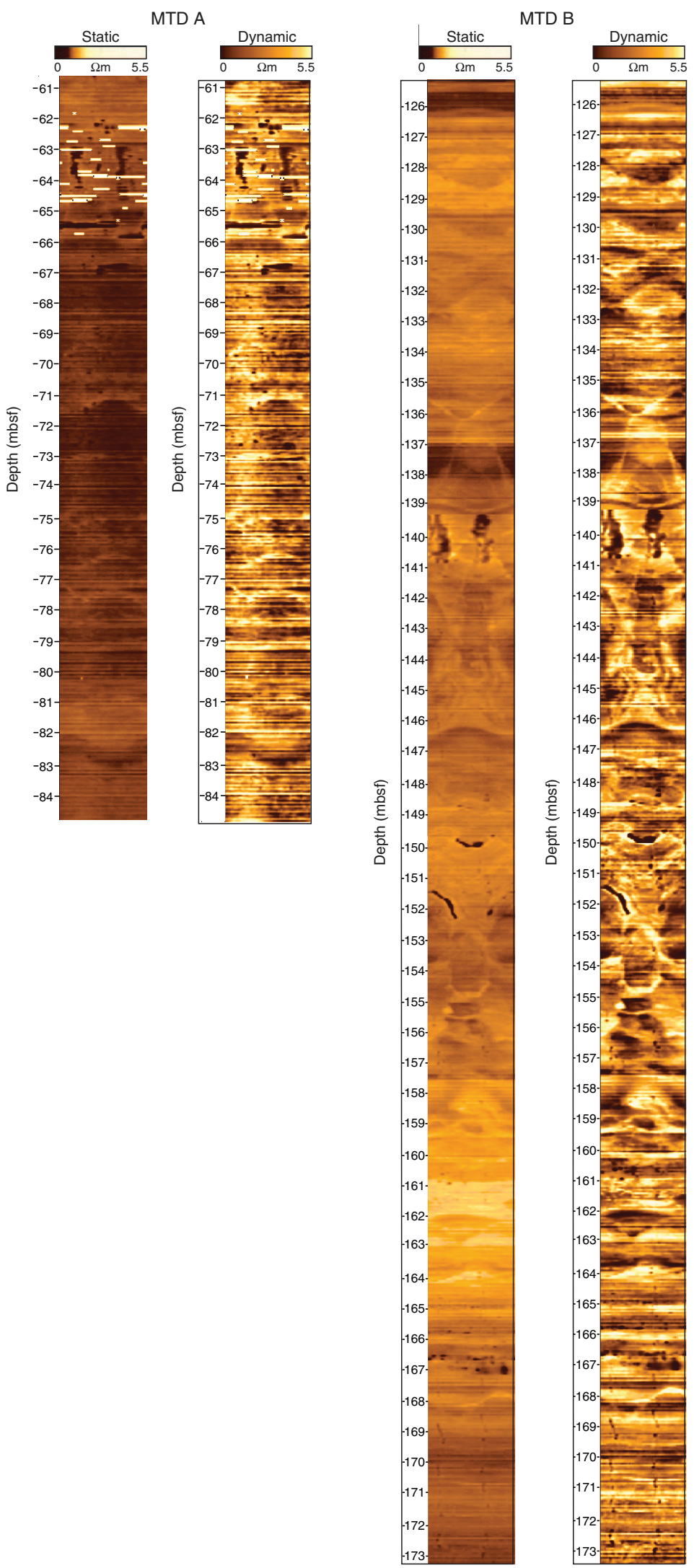
Figure F9. Conductive intervals at 180-183.0 mbsf in Hole C0018B. Small dark patches possibly demonstrate the occurrence of concentrated pyrite.
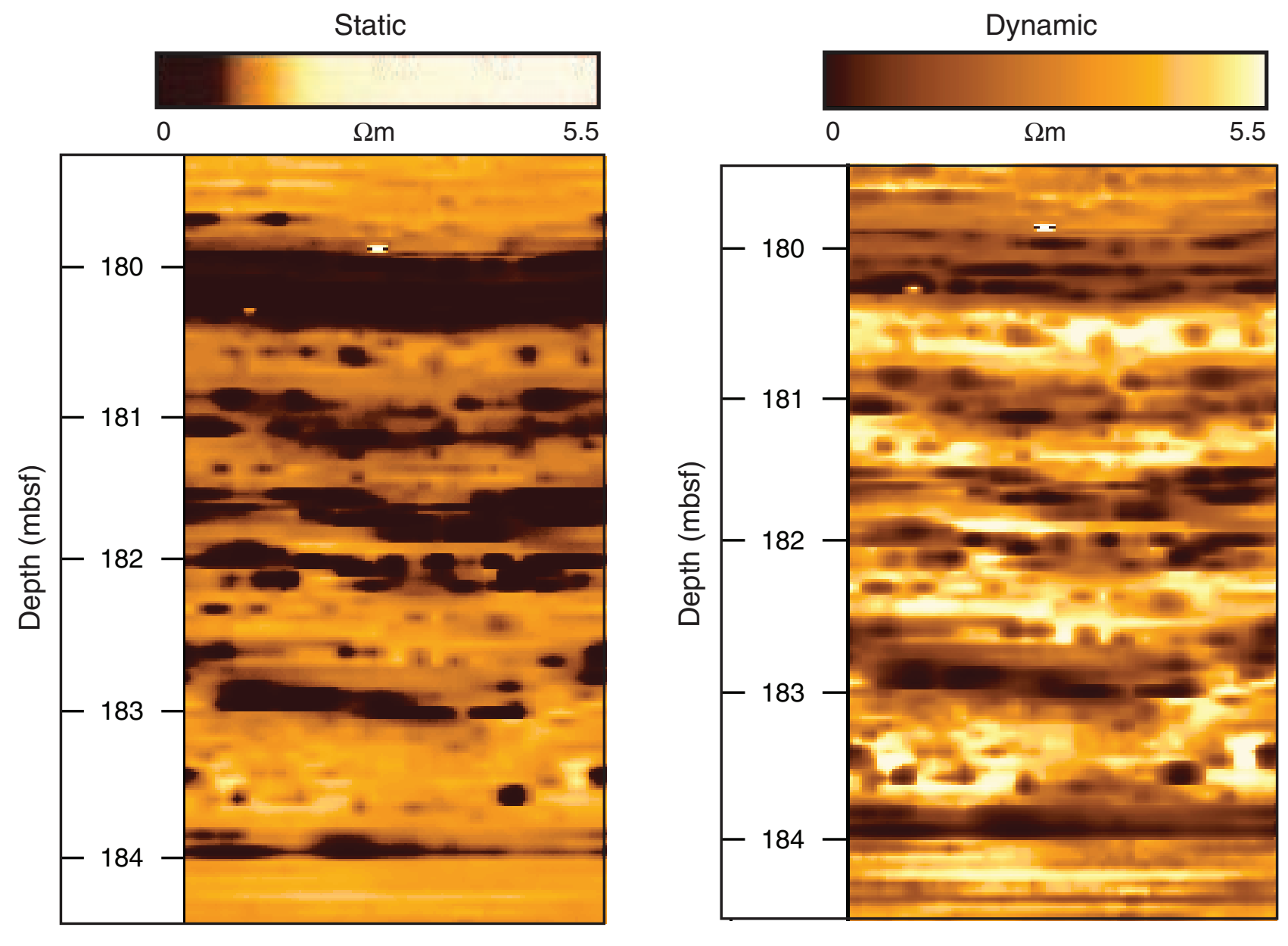
Figure F10. Plot of laboratory measured resistivity $\left(R_{\text {eff }}\right)$ against MAD-derived porosity from Expedition 333 Hole C0018A. Red line $=$ Archie's law fit with parameters $a=1.72, m=1.68$, and coefficient of determination $\left(R^{2}\right)=0.50$. Green line $=$ Archie's law with parameters estimated at Site C0002 $\left(a=1, m=2.4\right.$, and $\left.R^{2}=0.29\right)$.

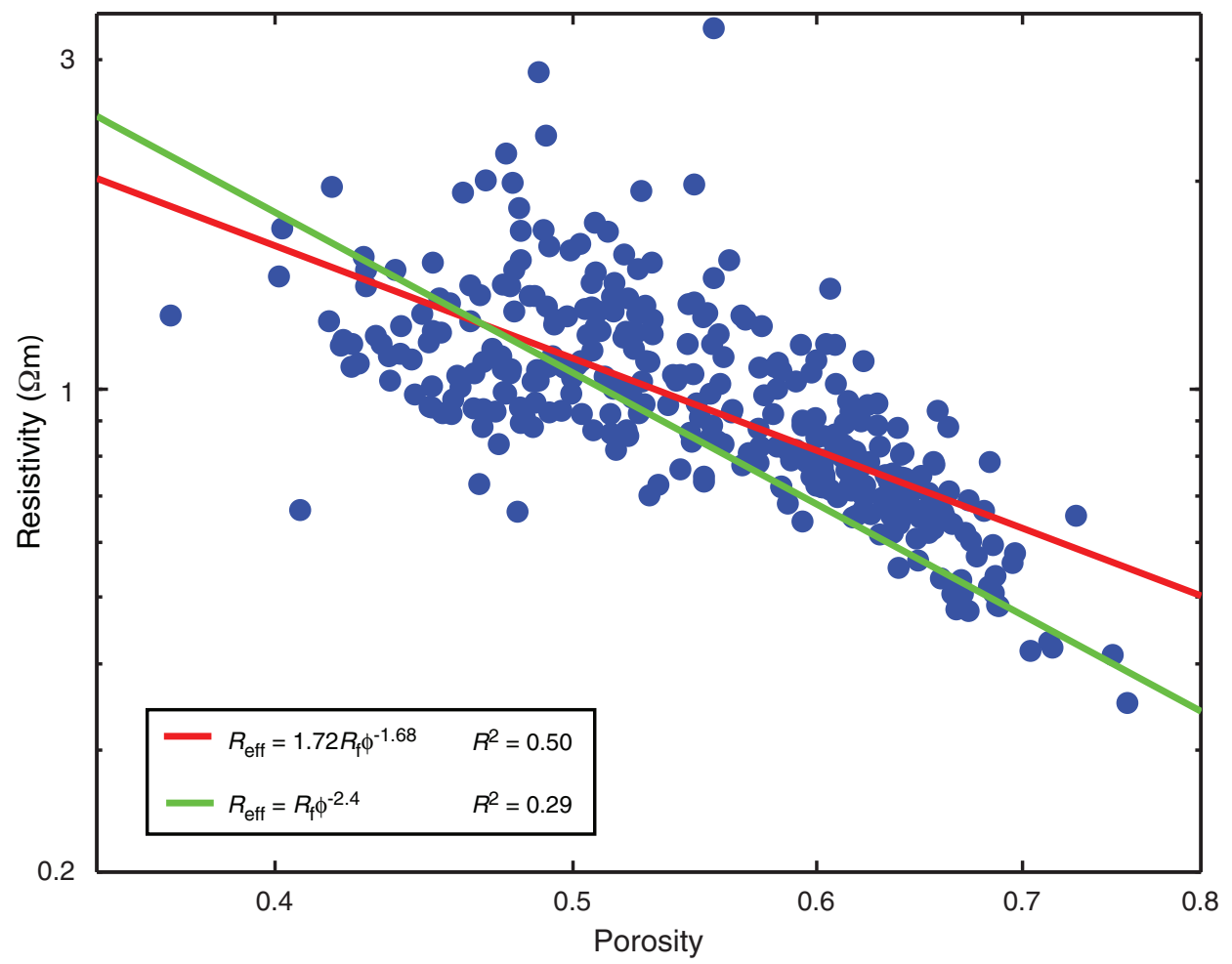


Figure F11. A. Resistivity-derived porosity plotted with moisture and density (MAD) porosity values from Expedition 333 (blue dots). Black line = resistivity-derived porosity using Archie parameters estimated from Expedition 333 Hole C0018A cores, red line = resistivity-derived porosity using Archie parameters estimated from Expedition 314 Hole C0002A LWD data, green lines $=\mathrm{a} 1$ standard deviation margin from the mean value of the resistivity-derived porosity trend using Hole C0018A Archie parameters. B. Offset $\Delta \phi=\phi_{\mathrm{MAD}}-\phi_{\text {resistivity }}$ between the MAD-derived and resistivityderived porosity data calculated using Archie parameters estimated for Site C0018. C. Resistivity-derived bulk density from porosity values shown by black line in $\mathrm{A}$.



B

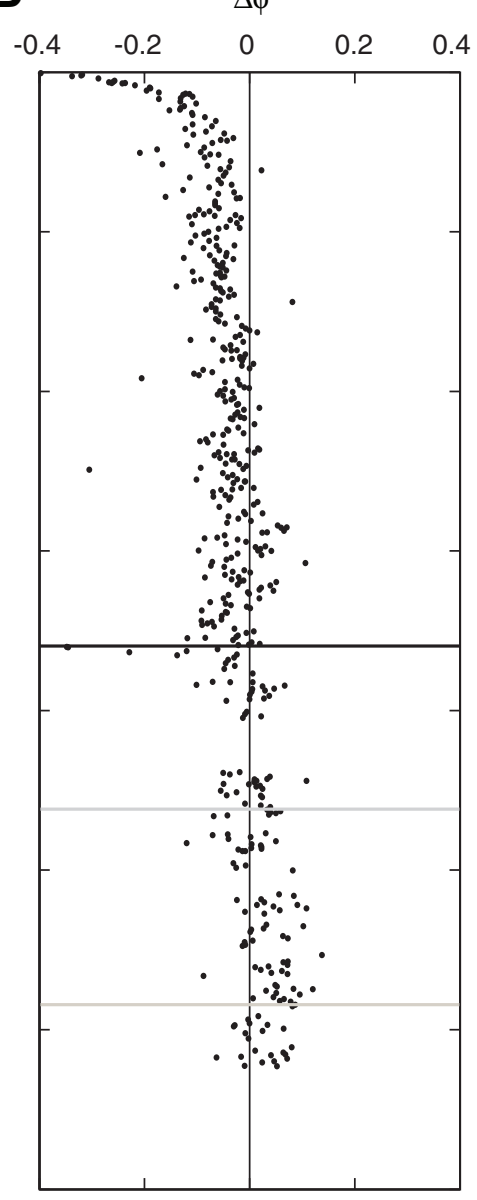

C

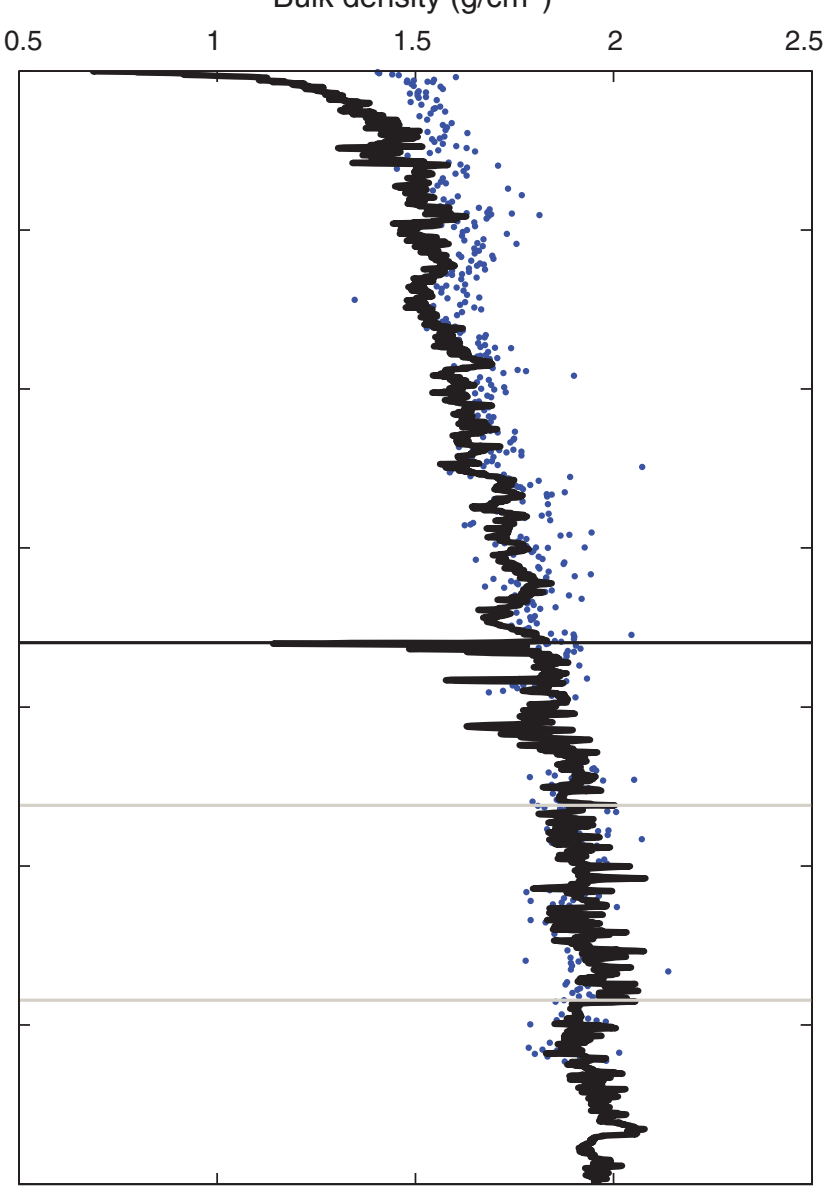


Figure F12. Core-log-seismic integration, Site C0018. LWD data from Hole C0018B, including tadpole plot of bedding dip angles and directions measured from resistivity images, with unit boundaries and mass transport deposit (MTD) intervals; seismic data from In-line 2315 of the Kumano 3-D PSDM volume (Moore et al., 2009); and core lithology from Hole C0018A with MTDs numbered successively from MTDs 1 to 6 (Expedition 333 Scientists, 2012b).
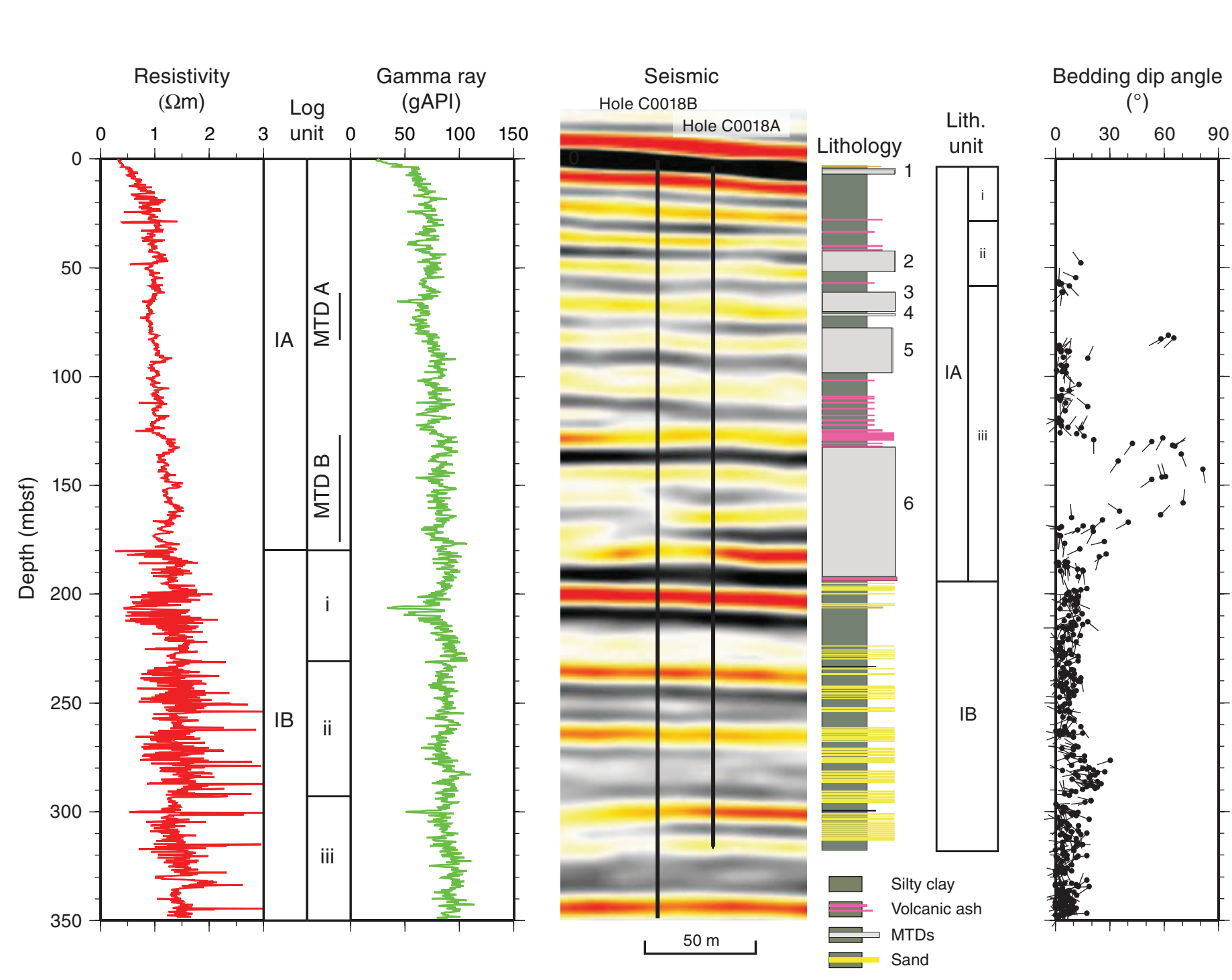

Medium resistivity

$(\Omega \mathrm{m})$

Static

$\begin{array}{lll}0.5 & 1.5 & 2.5\end{array}$

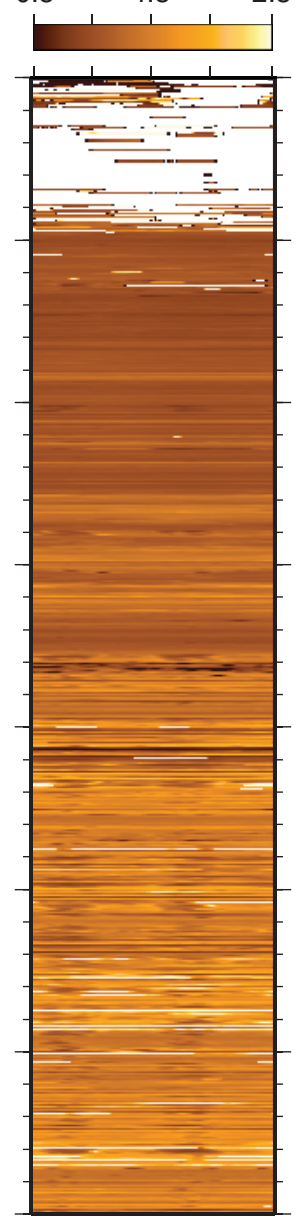


Table T1. Logging unit boundaries, Hole C0018B.

\begin{tabular}{llllc}
\hline $\begin{array}{l}\text { Log } \\
\text { unit Subunit }\end{array}$ & $\begin{array}{l}\text { Depth } \\
\text { (mbsf) }\end{array}$ & Interval & $\begin{array}{c}\text { Depth } \\
\text { (mbsf) }\end{array}$ \\
\hline I & IA & $0.0-179.8$ & MTD A & $61.5-83.0$ \\
& & & MTD B & $127.0-176.0$ \\
& IB & $179.8-350.0$ & IBi & $179.8-230.9$ \\
& & & IBii & $230.9-292.9$ \\
& & & IBiii & $292.9-350.0$ \\
\hline
\end{tabular}

MTD = mass transport deposit. 